\title{
Measurement and modeling of respirable particulate (PM10) and lead pollution over Madurai, India
}

\author{
B. Vijay Bhaskar • R. V. Jeba Rajasekhar • \\ P. Muthusubramanian • Amit P. Kesarkar
}

Received: 18 December 2007 / Accepted: 11 March 2008/Published online: 22 April 2008

(C) Springer Science + Business Media B.V. 2008

\begin{abstract}
Samples of particulate matter less than or equal to $10 \mu \mathrm{m}\left(\mathrm{PM}_{10}\right)$ were collected round the clock duration by using a respirable dust sampler (APM $460 \mathrm{BL}$ ) in Madurai, the second largest and most densely populated city of Tamil Nadu, India. The Environmental Protection Agency (EPA)-recommended standard methods were adopted not only for sample collection but also for subsequent analysis of respirable particulate pollutants. The observed $\mathrm{PM}_{10}$ concentrations varied from 88.1 to $226.9 \mu \mathrm{g} / \mathrm{m}^{3}$, and lead concentrations ranged between 0.21 to $1.18 \mu \mathrm{g} / \mathrm{m}^{3}$. The annual averages of the concentrations of the pollutants of current concern manifested that they were mostly below the Indian air quality standards and were generally comparable with those concentrations observed in most other Indian urban areas. The AERMOD model was validated simultaneously by comparing the predicted levels with the estimated levels of $\mathrm{PM}_{10}$. The generated database of the present investigation on the degree of pollution may be used for further research investigation and pollution abatement in the city.
\end{abstract}

Keywords Urban air pollution $\cdot$ Monitoring $\cdot \mathrm{PM}_{10} \cdot \mathrm{Pb}$. AERMOD

B. Vijay Bhaskar $(\bowtie) \cdot$ R. V. Jeba Rajasekhar •

P. Muthusubramanian

Department of Environment, School of Energy Sciences,

Madurai Kamaraj University,

Madurai 625 021, Tamil Nadu, India

e-mail: yajivbs@yahoo.co.in

\section{A. P. Kesarkar}

Computational Atmospheric Sciences,

Scientific and Engineering Computing Group,

Pune University Campus,

Pune 411 007, Maharastra, India

\section{Introduction}

It is well known that the health effects associated with the airborne particles are dependent on their toxicity. The extent to which air borne particles penetrate into the human respiratory system is mainly determined by the size of the penetrating particles (Balachandran et al. 2000). There are several epidemiological studies present in the literature (Dockery 1993; Hoek et al. 1997; Harrison and Yin 2000; Sammet et al. 2000), which have demonstrated a direct association between atmospheric inhalable particulate matter and respiratory diseases, pulmonary damage, and mortality especially in the urban areas. Therefore, the estimation of the levels of respirable particulate and its major toxic constituent lead $(\mathrm{Pb})$ present in the urban atmosphere is a prime requirement of epidemiological investigation, air quality management, and air pollution abatement (Chow et al. 2002; Querol et al. 2001). For this purpose, we have monitored the levels of particulate matter less than or equal to $10 \mu \mathrm{m}\left(\mathrm{PM}_{10}\right)$ and $\mathrm{Pb}$. In addition, we have modeled the dispersion of $\mathrm{PM}_{10}$ over Madurai, the second largest city in the state of Tamil Nadu, India. The measurements (sample collection) and chemical analysis were made using the standard method recommended by the Environmental Protection Agency (EPA), USA, for the period of 1 year viz. July 2005 to June 2006. To investigate the dispersion of pollutants over Madurai city, we have used AERMOD model (EPA 2005; Cimorelli et al. 2005; Kesarkar et al. 2007) developed by EPA. The results obtained from the monitoring of $\mathrm{PM}_{10}$ and $\mathrm{Pb}$ along with modeling of $\mathrm{PM}_{10}$ is presented in this investigation.

This paper is organized as follows. "Details of the experiments" of this paper presents the details of the monitoring of $\mathrm{PM}_{10}$ and $\mathrm{Pb}$ over Madurai city. The results of monitoring and modeling of $\mathrm{PM}_{10}$ dispersion using 
AERMOD, a steady-state plume dispersion model, are discussed in "Results and discussions." The major conclusions are presented in "Conclusions."

\section{Details of the experiments}

Monitoring of respirable particulate matter

Madurai city $\left(9^{\circ} 54^{\prime} \mathrm{N}, 78^{\circ} 84^{\prime} \mathrm{E}\right.$ and $100 \mathrm{~m}$ above sea level), popularly known as the City of Temples, has an important historical, cultural, and religious heritage in South India. This city has a surface area of $52.8 \mathrm{~km}^{2}$ with an estimated population of 1.2 million in 2001 (Jeba Rajasekhar et al. 2004). The ambient air quality of the city is greatly affected due to combustion of fossil fuels in stationary and mobile sources, and it was observed that the rate of combustion of fossil fuels had an increasing trend over the decades. To study the distribution of pollutants over Madurai city, the measurements of respirable particulate matter and $\mathrm{Pb}$ were carried out at six different sampling sites. The selections of these sites were made based on the existing anthropogenic activities occurring at these sites, which were responsible for atmospheric pollution. These anthropogenic activities included the varying density of road traffic, industrialization, and domestic activities within the urban limits of the city. The air samples were collected periodically for 1 year to estimate the concentrations of the particulate pollutants of current concern.

A description of the land use and likely sources of atmospheric pollution in the vicinity of the sites is given below.

\section{Periyar bus stand}

This is the main bus station situated at the heart of the city. The area of this bus station is very limited, and it is surrounded by narrow roads. Therefore, at this site, there are always traffic jams and congestion leading to slow movement of traffic. The contribution to air pollution at this site is mainly due to the emissions from public and commercial transportation (buses, trucks, autorickshaws, and two-wheelers). The accumulation of the air pollutants may be endured at this site due to the presence of tall roadside shops, houses, and buildings.

\section{Goripalayam}

This is a very busy commercial site located in the northern part of the city. A large number of shops, restaurants, and workshops, in addition to some Government establishments such as Government Rajaji Hospital (the biggest hospital in the southern Tamil Nadu region), colleges, and schools, are situated near this site. Although the roads are relatively wider than those at the central parts of the city, the movement of the traffic is highly congested and slow due to high density of vehicles and encroachment on the road sides.

\section{Palanganatham}

This site is surrounded by many cottages and small-scale industries mostly related to furniture, grill works, plastic, and rubber and also by lathe works, electroplating units, rice mills, and residential colonies. The continuous traffic flow witnessed at this site is due to the bus station located near by. Besides the emissions from automobiles, the emissions from commercial and domestic sectors contribute to the total air pollution load at this sampling site.

\section{Kochadai}

This is an industrial site of Madurai city, where two major coal-based rubber industries that produce rubber-based domestic appliances are situated. The National Highway (NH-47) Extension passing near this site has a substantial flow of traffic. Hence, the emissions from the industries and automobiles are the major sources of air pollution in this region. At this site, there are also some residential colonies of high-profile people.

\section{Pudur}

Pudur is a fast emerging extension area of the city with many residential colonies. There are also a number of Government offices, educational institutions, and commercial establishments in this area of study. Traffic flow consists mainly of light-tonnage vehicles especially twowheelers and heavy-tonnage vehicles mainly the public buses. Since the roads are narrow and their conditions are poor, traffic emissions are substantial. An industrial estate that consists of small-scale industries including electroplating and welding units is situated in the outskirts of Pudur, which may also contribute by means of background concentrations.

\section{Sree Meenakshi temple}

Having a large number of temples, Madurai is popularly referred as the temple city of south India. Sree Meenakshi temple, the landmark of the city, is located at the central part of the city. Around the temple, there are many commercial establishments. This causes the site to be very crowded with continuous traffic flow almost round the clock. The emissions from automobiles, commercial establishments, and residences contribute to the air pollution loads of this sampling site. 


\section{Topographical features of Madurai}

The topography of the Madurai city very slightly increases in all directions as one moves away from the heart of the city except in the south direction, and this city is surrounded by the gently sloping terrain. There are no hills in the region of the Madurai Corporation limit. Therefore, the existing topography of this city experiences horizontally homogeneous wind flow and more or less steady-state meteorological conditions. Such conditions do not allow the accumulation of pollutants (Benson 1989). However, for the central regions of this city, building geometry on both sides of the narrow roads is an important parameter for characterizing the transport and dispersion of pollutants. This geometry can be treated as a tunnel, which is open at the top, and this is commonly referred as street canyon. The elevated pollutant concentrations at some of the sampling sites, which are located in the central parts of the city, may also be determined by this parameter (Copper and Alley 1986; Buckland and Middleton 1999).

\section{Measurement of $\mathrm{PM}_{10}$ sampling}

The $\mathrm{PM}_{10}$ samples were collected round the clock duration by using commercially available Respirable Dust Sampler (Envirotech APM 460BL). The sampler had a free-flow condition without filter, and the flow rate of air sampler varied between 0.9 and $1.4 \mathrm{~m}^{3} / \mathrm{min}$. It could be operated up to $28 \mathrm{~h}$. Whatmann microfiber filter papers (EPM 2000) were used for the collection of $\mathrm{PM}_{10}$ particles. The glass fiber filter of the dimensions $8 \times 10 \mathrm{in}$. was used for this measurement in such a way that a $7 \times 9$-in. area of the filter was exposed on the respirable dust sampler. The centrifugal force method was adopted to remove the large particles. Continuous and simultaneous samplings were carried out at all the sites for a period of 1 year viz. July 2005 to June 2006. The ground level meteorological conditions required for air quality modeling viz. temperature, wind speed, wind direction, solar radiation, rainfall, and relative humidity were collected simultaneously on a 30 -min basis during sampling of $\mathrm{PM}_{10}$ for the period of July 2005 to June 2006.

\section{Chemical analysis of $\mathrm{PM}_{10}$ measurements}

For this study, airborne $\mathrm{PM}_{10}$ concentrations were determined gravimetrically using a system of filter papers. Filters used for $\mathrm{PM}_{10}$ particle collection were dried, before and after the weighing, in the high-volume desiccator under $5 \%$ relative humidity for $48 \mathrm{~h}$. Experiments of conservation, drying, and weighing were conducted in the dark room with relative humidity of $50 \pm 5 \%$ and temperature of $20 \pm 1^{\circ}$ C. The exposed filter paper was cut into $4 \times 5-\mathrm{cm}$ strips. The strips for the metal analysis were ashed in a low- temperature asher, and the ashed filter was then placed in a glass tube, which was treated with $10 \mathrm{ml}$ nitric acid, $5 \mathrm{ml}$ hydrochloric acid, and $5 \mathrm{ml}$ perchloric acid and warmed for $5 \mathrm{~h}$. To complete the digestion process, the digestion was done three times, and the sample was evaporated to dryness. The sample residues were dissolved in $1 \%$ nitric acid, cooled, and made up to $50 \mathrm{ml}$ in a volumetric flask with the help of double-distilled dematerialized water. Following the dilution, the samples were centrifuged at 2,000 rpm for about $30 \mathrm{~min}$, and the supernatant liquid was decanted into polypropylene tubes that were then capped and stored for pending analysis (Katz 1969; Tripathi 1994).

A blank filter paper was also similarly digested, and the same procedure was carried out. The analysis was subsequently made by atomic absorption spectroscopy (AAS). A commercially available AAS (Varian Spectra 220) was used to estimate the concentrations, which were calculated by comparing the absorbance of sample solutions with the standard metal solutions. The standard solutions for the metals under investigations were prepared from the stack solutions just before their utilization.

\section{Meteorological observations}

Meteorology plays a crucial role in air pollution studies. In fact, there is a strong seasonality in the meteorological factors, which modulates the air quality levels (Espinosa et al. 2004; Karar et al. 2005). The important meteorological variables having influence on the levels of the pollutants over Madurai are wind (speed and direction), rain (amount and duration), air temperature, and relative humidity (Singal and Prasad 2005). The analysis of the meteorological observations during the period of July 2005 to June 2006 showed the maximum solar radiation of $1,024 \mathrm{w} / \mathrm{m}^{2}$, and the highest atmospheric temperature of $44.8^{\circ} \mathrm{C}$ was recorded during the summer season (March-May). It was observed that the velocity of wind was maximum during the months of July (8.4), followed by August (6.8) and September (5.5) and ranged between 0.3 and $8.4 \mathrm{~m} / \mathrm{s}$. The predominant wind velocity was observed in the northeast monsoon season. In the summer months, the observed wind speed was relatively lower than those in the winter season and varied from 0.2 to $6.2 \mathrm{~m} / \mathrm{s}$. The predominant wind directions during the period of this study were northeast, east, southeast, and west. The maximum number of rainy days (41) and the average maximum rainfall $(501 \mathrm{~mm})$ took place in the month of October followed by November due to presence of the northeast monsoon. The variation of relative humidity showed a steep decrease from winter to summer $(66 \%$ to $57 \%)$ and then a slow increase in the rainy season $(67 \%$ to $78 \%)$ and remained steady in winter $(68 \%)$. 


\section{Results and discussions}

\section{Statistical analysis}

The observed $\mathrm{PM}_{10}$ and lead concentrations are summarized in Tables 1 and 2, respectively. It was observed that the maximum average $\mathrm{PM}_{10}$ concentration was found at Goripalayam (site 2) followed in decreasing order by Periyar (site 1), Pudur (site 5), Palanganatham (site 3), Kochadai (site 4), and Sree Meenakshi Temple (site 6), respectively. The maximum standard deviation was observed for Goripalayam (site 2) followed in decreasing order by Periyar (site 1), Kochadai (site 4), Sree Meenakshi Temple (site 6), Pudur (site 5), and finally for the Palanganatham (site 3). Similarly, it was observed that the average concentration of $\mathrm{Pb}$ was highest at Goripalayam (site 2) followed in decreasing order by the Periyar (site 1), Palanganatham (site 3), Pudur (site 5), Kochadai (site 4), and Sree Meenakshi Temple (site 6). The Goripalayam (site 2) had maximum variability of $\mathrm{Pb}$ concentrations with the standard deviation of $16 \%$.

$\mathrm{PM}_{10}$ had a very good positive correlation with atmospheric temperature (0.71 to 0.91$)$ and a negative correlation with humidity (0.68 to 0.94$)$ at most of the sampling stations. In the case of multiple regression analysis, it was found that $\mathrm{PM}_{10}$ had a positive relationship with temperature (0.33 to 0.49$)$ in most of the sampling stations. The qualitative information revealed by the statistical analysis indicated that the temperature had a positive correlation (0.49) with particulate pollutant concentrations. However, in the case of $\mathrm{Pb}$, temperature, wind speed, and humidity had no correlation. The calculated coefficient of variance (CV), which is a measure of the correlation between two ranges of data (Zar 2004), of the recorded concentrations of $\mathrm{PM}_{10}$ were $16.4 \%, 19.6 \%$, $8.5 \%, 23.1 \%, 10.7 \%$, and $13.9 \%$ for the sites Periyar bus stand, Goripalayam, Palanganatham, Kochadai, Pudur, and Sree Meenakshi Temple, respectively. Similarly, calculated $\mathrm{CV}$ of the recorded concentrations of $\mathrm{Pb}$ were $14.1 \%$, $18.4 \%, 14.6 \%, 16.7 \%, 18.0 \%$, and $12.2 \%$ for the sites
Periyar bus stand, Goripalayam, Palanganatham, Kochadai, Pudur, and Sree Meenakshi Temple, respectively. The calculated $\mathrm{CV}$ of the recorded concentrations ranged from $8.5 \%$ to $23.1 \%$ for $\mathrm{PM}_{10}$ and from $12.2 \%$ to $18.4 \%$ for $\mathrm{Pb}$ (Tables 3 and 4).

\section{Seasonal distribution}

To understand the seasonal variability of the concentrations of pollutants, seasonal distribution has been calculated, and it is presented in Tables 5 and 6. It was observed from Table 5 that $\mathrm{PM}_{10}$ had the maximum concentrations in the summer season (March-May) and minimum concentrations during monsoon season (June-September). The highest concentration of particulate matter in summer might be described with photochemical reactions along with other factors like source strength and other meteorological parameters. The lowest concentration of $\mathrm{PM}_{10}$ in the monsoon could be attributed to the scavenging of particulate pollutants from the atmosphere due to rainfall (Stern 1976). The maximum variability of $\mathrm{PM}_{10}$ was observed at site 2 during the southwest monsoon season. The concentration of $\mathrm{Pb}$ (Table 6) showed nearly the same average concentrations at all sites except at sites 1 and 2 during all seasons. The maximum variability of $\mathrm{Pb}$ was observed at site 6 with a CV equal to $21.9 \%$ (Table 7 ).

\section{Monthly distribution}

The monthly variations of concentrations of $\mathrm{PM}_{10}$ and $\mathrm{Pb}$ are depicted in Fig. 1a-f. From this figure, it was noticed that the month of May showed the highest recorded $\mathrm{PM}_{10}$ levels in all sites, whereas the lowest concentration could be observed in the month of December. The summer season had an average value of $158.8 \mu \mathrm{g} / \mathrm{m}^{3}$, whereas a winter month had an average value of $109.1 \mu \mathrm{g} / \mathrm{m}^{3}$. The lowest recorded $\mathrm{Pb}$ levels among all the sampling sites was $0.52 \mu \mathrm{g} / \mathrm{m}^{3}$ in the summer month, whereas the highest concentration of $\mathrm{Pb}$ could be observed in December, a winter month, with an average value of $0.66 \mu \mathrm{g} / \mathrm{m}^{3}$.
Table 1 Summary of $\mathrm{PM}_{10}$ concentrations at six sites of Madurai city

\begin{tabular}{|c|c|c|c|c|c|c|c|c|}
\hline \multirow[t]{3}{*}{ Sl number } & \multirow[t]{3}{*}{ Site } & \multicolumn{7}{|c|}{$\mathrm{PM}_{10}$ concentration $\left(\mu \mathrm{g} / \mathrm{m}^{3}\right)$} \\
\hline & & \multicolumn{3}{|c|}{ Percentile } & \multirow[t]{2}{*}{ Max } & \multirow[t]{2}{*}{ Min } & \multirow[t]{2}{*}{ Mean } & \multirow[t]{2}{*}{ SD } \\
\hline & & 25 th & 50 th & 75 th & & & & \\
\hline 1 & Site 1 & 134.9 & 147.2 & 175.2 & 210.4 & 108.5 & 152.9 & 25.2 \\
\hline 2 & Site 2 & 139.1 & 170.9 & 190.7 & 226.9 & 108.5 & 166.8 & 32.8 \\
\hline 3 & Site 3 & 121.2 & 126.1 & 135.1 & 149.5 & 100.2 & 127.8 & 10.9 \\
\hline 4 & Site 4 & 80.8 & 89.6 & 111.1 & 149.5 & 70.5 & 97.2 & 22.5 \\
\hline 5 & Site 5 & 120.1 & 130.7 & 139.6 & 155.2 & 102.1 & 129.4 & 13.9 \\
\hline 6 & Site 6 & 102.0 & 115.2 & 129.1 & 145.1 & 88.1 & 115.6 & 16.1 \\
\hline
\end{tabular}


Table 2 Summary of $\mathrm{Pb}$ concentrations at six sites of Madurai city

\begin{tabular}{|c|c|c|c|c|c|c|c|c|}
\hline \multirow[t]{3}{*}{ Sl number } & \multirow[t]{3}{*}{ Site } & \multicolumn{7}{|c|}{$\mathrm{Pb}$ concentration $\left(\mu \mathrm{g} / \mathrm{m}^{3}\right)$} \\
\hline & & \multicolumn{3}{|c|}{ Percentile } & \multirow[t]{2}{*}{ Max } & \multirow[t]{2}{*}{ Min } & \multirow[t]{2}{*}{ Mean } & \multirow[t]{2}{*}{ SD } \\
\hline & & 25 th & 50 th & 75 th & & & & \\
\hline 1 & Site 1 & 0.78 & 0.86 & 0.93 & 1.07 & 0.49 & 0.85 & 0.12 \\
\hline 2 & Site 2 & 0.76 & 0.86 & 0.97 & 1.18 & 0.49 & 0.87 & 0.16 \\
\hline 3 & Site 3 & 0.44 & 0.49 & 0.52 & 0.76 & 0.31 & 0.48 & 0.07 \\
\hline 4 & Site 4 & 0.39 & 0.42 & 0.44 & 0.62 & 0.21 & 0.42 & 0.07 \\
\hline 5 & Site 5 & 0.42 & 0.51 & 0.58 & 0.71 & 0.35 & 0.50 & 0.09 \\
\hline 6 & Site 6 & 0.46 & 0.49 & 0.52 & 0.62 & 0.38 & 0.49 & 0.06 \\
\hline
\end{tabular}

The Department of Environment, School of Energy, Environment, and Natural Resources, Madurai Kamaraj University, studied the levels of pollution at various locations in Madurai city since 1987. In fact, there is continuous measurement of particulate levels in the ambient air of Madurai city from the year 1998. The recorded average concentrations of particulate matter are shown in Fig. 2. It is obvious from the figure that the concentration of particulate pollutants shows an upward trend during the years.

Modeling of air quality

AERMOD is a steady-state plume dispersion model for the assessment of pollutant concentrations from a variety of sources (EPA 2005; Cimorelli et al. 2005; Kesarkar et al. 2007). AERMOD has an improved approach for characterizing the fundamental boundary layer parameters and vertical profile of the atmosphere along with better representation of plume buoyancy, penetration, and urban nighttime boundary layer (Cimorelli et al. 2005) as compared to the industrial source complex (ISC) model. It provides variable urban treatment of vertical dispersion as a function of city population and can selectively model sources as rural or urban. AERMOD requires hourly surface and upper air meteorological observations for simulating the pollutant dispersion. AERMOD simulates transport and dispersion from multiple points, area, or volume sources based on an up-to-date characterization of the atmospheric boundary layer. Sources may be located in the rural or urban areas, and receptors may be located in simple or complex terrain. AERMOD also accounts for building wake effects (i.e., plume downwash). The model employs hourly sequential preprocessed meteorological data to estimate concentrations for averaging times from $1 \mathrm{~h}$ to 1 year (EPA 2004). This model assumes the probability distribution function for the concentration of a pollutant to be Gaussian both in the vertical as well as horizontal directions in a stable boundary layer. In the convective boundary layer, the horizontal dispersion is Gaussian, whereas the vertical distribution is represented by a bi-Gaussian probability distribution function. The vertical distribution required meteorological variables that are generated based on meteorological observations using a similarity relationship. The AERMOD model has a AERMET processor to calculate planetary boundary layer parameters viz. friction velocity, Monin-Obukhov length, convective velocity scale, temperature scale, mixing height, surface heat flux by using local surface characteristics in the form of surface roughness, and Bowen ratio in combination with standard meteorological observations (wind speed, wind direction, temperature, and cloud cover). Then, these parameters are used to calculate vertical profiles of wind speed, lateral and vertical turbulent fluctuations, and the potential temperature gradient in AERMOD. This model is intended to be useful for the simulation of short-range $(<50 \mathrm{~km})$ pollutant dispersion.

The AERMOD model assumes that the plume exists in two states and that the concentration at a receptor, located at a position $(x, y, z)$, is the weighted sum of the two concentration estimates. While the first one is where the plume is horizontal (representing plume material below the dividing streamline), the other one is where the plume travels over the terrain (representing plume material above the dividing streamline). Under stable conditions, the horizontal plume "dominates" and is given greater weight, while under neutral and unstable conditions, the plume traveling over the terrain is more important (heavily
Table 3 Multiple regression coefficients for $\mathrm{PM}_{10}$ pollutant

\begin{tabular}{lrcrrrr}
\hline Variables & Site 1 & Site 2 & Site 3 & Site 4 & Site 5 & Site 6 \\
\hline Temperature & 0.38 & 0.50 & -0.40 & 0.43 & 0.44 & 0.48 \\
Wind speed & -0.33 & -0.27 & -0.26 & -0.38 & -0.30 & -0.27 \\
Humidity & -0.18 & 0.062 & -0.19 & -0.10 & -0.19 & -0.15 \\
\hline
\end{tabular}


Table 4 Multiple regression coefficients for $\mathrm{Pb}$ pollutant

\begin{tabular}{lrrrrrr}
\hline Variables & Site 1 & Site 2 & Site 3 & Site 4 & Site 5 & Site 6 \\
\hline Temperature & -0.09 & -0.10 & -0.20 & 0.06 & -0.24 & -0.20 \\
Wind speed & -0.39 & 0.07 & 0.19 & 0.13 & 0.17 & -0.06 \\
Humidity & -0.09 & 0.30 & 0.08 & 0.15 & 0.09 & 0.05 \\
\hline
\end{tabular}

weighted). In flat terrain, the concentration equation reduces to the form for a single plume. The general form for the total concentration at any terrain elevation is:

$C_{\mathrm{t}}(x, y, z)=f_{*} C(x, y, z)+(1-f)_{*} C\left(x, y, z_{\mathrm{eff}}\right)$

where $C(x, y, z)$ is the flat-terrain concentration equation appropriate for given stability conditions, $z$ is the height of the receptor (this includes the height above local terrain), $f$ is the weighting factor related to the fraction of plume material that is below the height, $H_{\mathrm{c}}$, of the dividing streamline, and $z_{\text {eff }}$ is an "effective" receptor height (which is equal to $z$ in flat terrain). The first term on the right-hand side of Eq. 1 represents the contribution from the horizontal plume and is evaluated at a receptor height $(z)$, whereas the second represents the contribution from the plume adjusted by terrain and is evaluated at an effective receptor height.

The form of the AERMOD concentration expression $C$ $(x, y, z)$ in Eq. 1 that is appropriate for stable conditions $(L>$ 0 ) in flat terrain (and is similar to that of ISC2) is the Gaussian expression:

$C(x, y, z)=Q / U \times F z(x, z, h p) F y(y)$

where

$$
\begin{aligned}
F_{z}= & \frac{1}{\sqrt{ } 2 \pi \sigma_{z}} \\
& \times \sum_{n=\infty}^{\infty}\left[\exp \left[\frac{\left(z-h_{\mathrm{p}}+2 n h_{\mathrm{a}}\right)^{2}}{2 \sigma_{z}^{2}}\right]+\exp \left[\frac{\left(z+h_{\mathrm{p}}+2 n h_{\mathrm{a}}\right)^{2}}{2 \sigma_{z}^{2}}\right]\right]
\end{aligned}
$$

$F_{y}=\frac{1}{\sqrt{ } 2 \pi \sigma_{y}} \exp \left[\frac{y^{2}}{2 \sigma_{y}^{2}}\right]$
In these equations, plume dilution and plume spread are calculated using effective boundary layer variables. In fact, $h_{\mathrm{p}}$ is the plume height, $\sigma_{y}$ and $\sigma_{z}$ are plume dispersion parameters, and $h_{\mathrm{a}}$ is the level where vertical mixing is limited $\left(=\max \left(h_{\mathrm{p}}, h\right)\right)$ where $h$ is the stable (mechanical) mixed layer height and $h_{\mathrm{p}}$ is equal to the stack height plus plume rise $(\Delta h)$.

For unstable conditions, AERMOD uses the expression,

$$
\begin{aligned}
C_{d}(x, O, z)= & \frac{Q}{2 \pi U \sigma_{y}} \frac{\lambda_{1}}{\sigma_{2 d 1}} \sum_{m=0}^{\infty}\left[\exp \left(-\frac{\left(z-h_{\mathrm{ed} i}-2 m z_{i}\right)^{2}}{2 \sigma_{2 d 1}^{2}}\right)\right. \\
& \left.+\exp \left(-\frac{\left(z+h_{\mathrm{ed} 1}+2 m z_{i}\right)^{2}}{2 \sigma_{2 d 1}^{2}}\right)\right] \\
& +\frac{\lambda_{2}}{\sigma_{2 d 2}} \sum_{m=0}^{\infty}\left[\exp \left(-\frac{\left(z-h_{\mathrm{ed} 2}-2 m z_{i}\right)^{2}}{2 \sigma_{2 d 2}^{2}}\right)\right. \\
& \left.+\exp \left(-\frac{\left(z+h_{\mathrm{ed} 2}+2 m z_{i}\right)^{2}}{2 \sigma_{2 d 2}^{2}}\right)\right]
\end{aligned}
$$

In fact, $h_{\mathrm{ed} i}$ and $\sigma_{\mathrm{zd} j}$ are the effective source height and vertical dispersion parameter, and $\sigma_{\mathrm{b}}$ is the dispersion due to buoyancy-induced entrainment. Equation 5 is the general expression for the concentration distribution along the plume center line. By providing the required inputs like emission and meteorological factors, the concentrations for the pollutants at all the sampling stations of the present investigation were predicted by using the AERMOD model.

The emissions of particulate matter in the study area are characterized by anthropogenic sources like transportation, industries, and domestic activities. There are two major

\begin{tabular}{|c|c|c|c|c|c|}
\hline \multirow{2}{*}{$\begin{array}{l}\text { Sl } \\
\text { number }\end{array}$} & \multirow[t]{2}{*}{ Site } & \multicolumn{4}{|c|}{$\mathrm{PM}_{10}$ seasonal concentrations $\left(\mu \mathrm{g} / \mathrm{m}^{3}\right)$} \\
\hline & & $\begin{array}{l}\text { Southwest } \\
\text { monsoon }\end{array}$ & $\begin{array}{l}\text { Northeast } \\
\text { monsoon }\end{array}$ & Winter & Summer \\
\hline 1 & Site 1 & $146.1(\mathrm{CV}=10 \%)$ & $130.2(\mathrm{CV}=9.2 \%)$ & $147.5(\mathrm{CV}=8.9 \%)$ & $187.8(\mathrm{CV}=8.0 \%)$ \\
\hline 2 & Site 2 & $163.2(\mathrm{CV}=20.1 \%)$ & $149.3(\mathrm{CV}=15.8 \%)$ & $152.3(\mathrm{CV}=18.1 \%)$ & $202.4(\mathrm{CV}=7.6 \%)$ \\
\hline 3 & Site 3 & $135.3(\mathrm{CV}=6.1 \%)$ & $115.8(\mathrm{CV}=6.6 \%)$ & $128.5(\mathrm{CV}=13.7 \%)$ & $137.9(\mathrm{CV}=5.7 \%)$ \\
\hline 4 & Site 4 & $126.0(\mathrm{CV}=4.1 \%)$ & $119.8(\mathrm{CV}=7.9 \%)$ & $126.0(\mathrm{CV}=8.4 \%)$ & $139.4(\mathrm{CV}=5.1 \%)$ \\
\hline 5 & Site 5 & $116.5(\mathrm{CV}=9.1 \%)$ & $102.9(\mathrm{CV}=10.2 \%)$ & $109.4(\mathrm{CV}=13.9 \%)$ & $133.4(\mathrm{CV}=6.8 \%)$ \\
\hline 6 & Site 6 & $89.0(\mathrm{CV}=14.8 \%)$ & $79.8(\mathrm{CV}=4.6 \%)$ & $96.3(\mathrm{CV}=19.0 \%)$ & $123.8(\mathrm{CV}=17.5 \%)$ \\
\hline
\end{tabular}
industries that produce rubber-based domestic and commercial appliances. The domestic activities mainly include
Table 5 Seasonal variations of $\mathrm{PM}_{10}$ concentrations in Madurai city 
Table 6 Seasonal variations of $\mathrm{Pb}$ concentrations in Madurai city

\begin{tabular}{|c|c|c|c|c|c|}
\hline \multirow{2}{*}{$\begin{array}{l}\text { S1 } \\
\text { number }\end{array}$} & \multirow[t]{2}{*}{ Site } & \multicolumn{4}{|c|}{ Seasonal concentrations $\left(\mu \mathrm{g} / \mathrm{m}^{3}\right)$} \\
\hline & & $\begin{array}{l}\text { Southwest } \\
\text { monsoon }\end{array}$ & $\begin{array}{l}\text { Northeast } \\
\text { monsoon }\end{array}$ & Winter & Summer \\
\hline 1 & Site 1 & $0.92(\mathrm{CV}=7.6 \%)$ & $0.76(\mathrm{CV}=10.0 \%)$ & $0.80(\mathrm{CV}=16.0 \%)$ & $0.90(\mathrm{CV}=13.8 \%)$ \\
\hline 2 & Site 2 & $0.70(\mathrm{CV}=12.0 \%)$ & $0.87(\mathrm{CV}=13.5 \%)$ & $0.92(\mathrm{CV}=6.0 \%)$ & $0.93(\mathrm{CV}=18.0 \%)$ \\
\hline 3 & Site 3 & $0.56(\mathrm{CV}=13.5 \%)$ & $0.43(\mathrm{CV}=16.1 \%)$ & $0.48(\mathrm{CV}=16.9 \%)$ & $0.55(\mathrm{CV}=10.6 \%)$ \\
\hline 4 & Site 4 & $0.49(\mathrm{CV}=8.7 \%)$ & $0.49(\mathrm{CV}=13.3 \%)$ & $0.48(\mathrm{CV}=12.5 \%)$ & $0.49(\mathrm{CV}=13.0 \%)$ \\
\hline 5 & Site 5 & $0.51(\mathrm{CV}=5.3 \%)$ & $0.45(\mathrm{CV}=17.0 \%)$ & $0.47(\mathrm{CV}=17.2 \%)$ & $0.51(\mathrm{CV}=17.9 \%)$ \\
\hline 6 & Site 6 & $0.44(\mathrm{CV}=9.2 \%)$ & $0.39(\mathrm{CV}=15.2 \%)$ & $0.39(\mathrm{CV}=13.4 \%)$ & $0.45(\mathrm{CV}=21.9 \%)$ \\
\hline
\end{tabular}

burning of fuels like liquefied petroleum gas, kerosene, fuel wood, and agricultural residues. To generate an emission inventory, a traffic survey was conducted by the physical counting of automobiles round the clock all over the city including the sampling stations of the present investigation. In fact, the study area was divided into a number of square grids of $1 \mathrm{~km}$ dimension. The total kilometer run for each

Table 7 Automobile source strength of particulate pollutants

\begin{tabular}{|c|c|c|c|}
\hline S1 Number & Survey points & $\begin{array}{l}\text { PM emissions } \\
\left(10^{-3} \mathrm{~g} \mathrm{~m}^{-1} \mathrm{~s}^{-1}\right)\end{array}$ & $\begin{array}{l}\text { Pb emissions } \\
\left(10^{-3} \mathrm{~g} \mathrm{~m}^{-1} \mathrm{~s}^{-1}\right)\end{array}$ \\
\hline 1 & $\begin{array}{l}\text { West Tower } \\
\text { street }\end{array}$ & 53.41 & 1.949 \\
\hline 2 & $\begin{array}{c}\text { West Masi } \\
\text { street }\end{array}$ & 84.69 & 2.656 \\
\hline 3 & $\begin{array}{l}\text { North Masi } \\
\text { street }\end{array}$ & 51.84 & 1.422 \\
\hline 4 & East Masi street & 75.32 & 2.260 \\
\hline 5 & $\begin{array}{l}\text { South Masi } \\
\text { street }\end{array}$ & 126.80 & 3.910 \\
\hline 6 & Nethaji street & 122.24 & 3.849 \\
\hline 7 & East Veli street & 119.74 & 3.183 \\
\hline 8 & Simmakkal & 202.99 & 6.168 \\
\hline 9 & South Gate & 114.25 & 2.724 \\
\hline 10 & Nirmala School & 196.21 & 5.022 \\
\hline 11 & Madura College & 226.52 & 6.466 \\
\hline 12 & Aarapalayam & 115.01 & 2.754 \\
\hline 13 & Kalavasal & 233.85 & 6.599 \\
\hline 14 & Sellur & 87.82 & 2.427 \\
\hline 15 & Avaniyapuram & 172.44 & 4.468 \\
\hline 16 & $\begin{array}{l}\text { Corporation } \\
\text { office }\end{array}$ & 198.99 & 5.517 \\
\hline 17 & Jaihind Puram & 77.05 & 1.943 \\
\hline 18 & Kochadai* & 119.88 & 3.497 \\
\hline 19 & Anna bus stand & 146.76 & 3.989 \\
\hline 20 & K. Pudhur* & 130.66 & 3.587 \\
\hline 21 & Periyar* & 374.86 & 10.237 \\
\hline 22 & Goripalayam* & 410.64 & 12.358 \\
\hline 23 & Palanganatham* & 197.05 & 5.324 \\
\hline 24 & $\begin{array}{l}\text { Meenakshi } \\
\text { Temple* }\end{array}$ & 100.98 & 3.084 \\
\hline 25 & Teppakulam & 91.81 & 2.544 \\
\hline
\end{tabular}

*Sampling stations grid was developed by using the data on number of vehicles and road lengths. The automobile source strength was calculated subsequently by using the total kilometer run by the vehicles and the emission rate of Indian vehicles.

The calculated automobile source strengths with special reference to particulate matter and lead all over the city showed that they ranged from $51.84 \times 10^{-3}$ to $410.64 \times 10^{-3}$ and from $1.42 \times 10^{-3}$ to $12.36 \times 10^{-3} \mathrm{~g} \mathrm{~m}^{-1} \mathrm{~s}^{-1}$, respectively. In the case of particulate matter emissions, it was noted that the heavy-tonnage vehicles had relatively higher emission rates than the medium-tonnage vehicles. The two- and three-wheelers also contributed notably (more than $70 \%$ at many traffic areas) in the total lead load of Madurai city. Even though the lead emission factor $(\mathrm{g} / \mathrm{km})$ for two- and three-wheelers is relatively lower in comparison with medium-tonnage vehicles, their contribution was about three to five times greater, which was due to the operation of a large number of motorized two- and three-wheelers (Pundir et al. 1994; Sivacoumar 1990). The automobilebased emission inventory was prepared, and it was used to initialize the AERMOD model. The emission inventory was generated for the sampling period only. However, the annual emission inventory by our team for both stationary and mobile sources is being generated for further research studies.

In the present paper, AERMOD was used for the prediction of $\mathrm{PM}_{10}$, and it was compared with the observations recorded during experiments. Figure $3 \mathrm{a}-\mathrm{f}$ showed the variation of predicted and observed concentrations of $\mathrm{PM}_{10}$ at all six different sites, respectively. The predicted concentrations ranged from 121.7 to $226.9 \mu \mathrm{g} / \mathrm{m}^{3}$ for $\mathrm{PM}_{10}$. It was noticed that sites 1 and 2 had the highest observed and predicted $\mathrm{PM}_{10}$ concentrations, which might be attributed directly to the traffic emissions, use of biomass for cooking, paved and unpaved road (resuspension) dusts, vehicular exhausts, and diesel-based electric generators in these sampling sites. It was observed from the generated database pertaining to the predicted and observed concentrations that the pattern of variation of predicted and observed concentrations behaved consistently, even though AERMOD underpredicted pollutants by a factor of $1-1.5$ in 
a

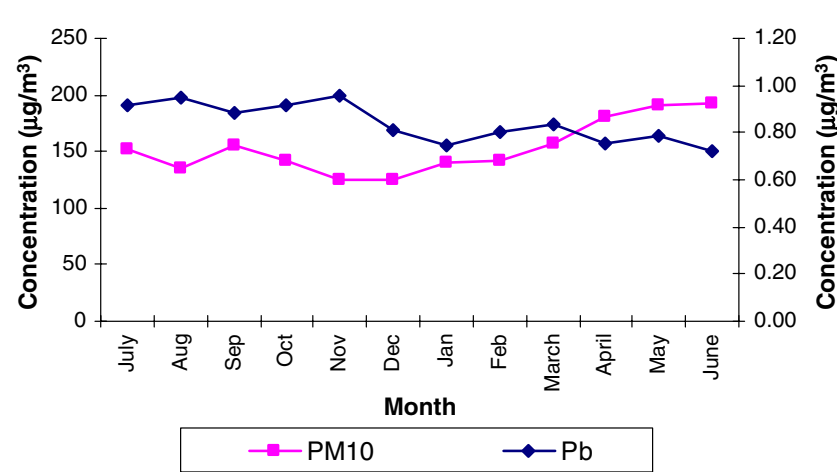

b

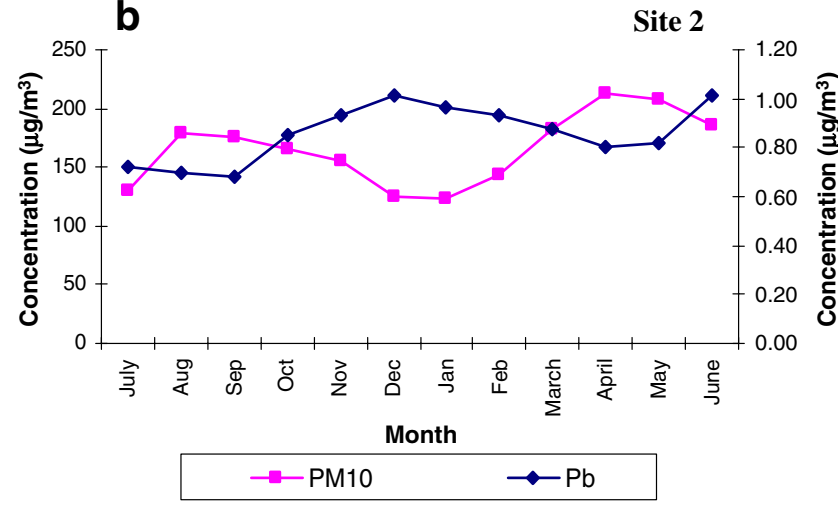

c

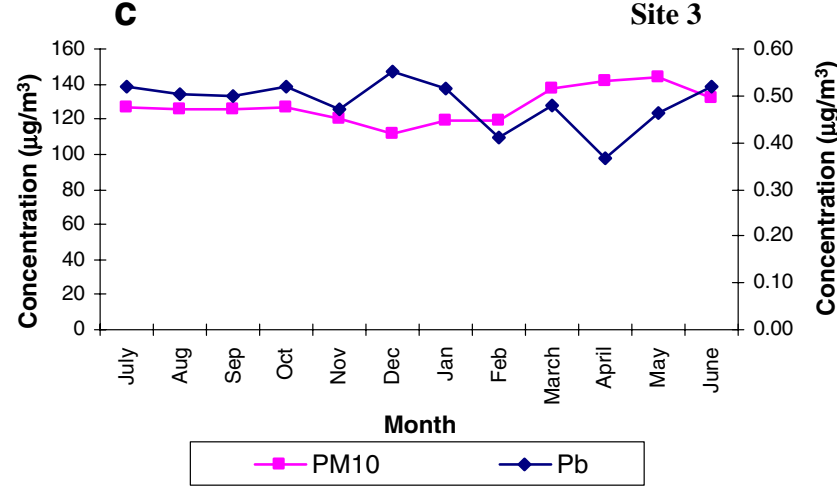

Fig. 1 a-f Monthly average pollutants concentrations at different sites

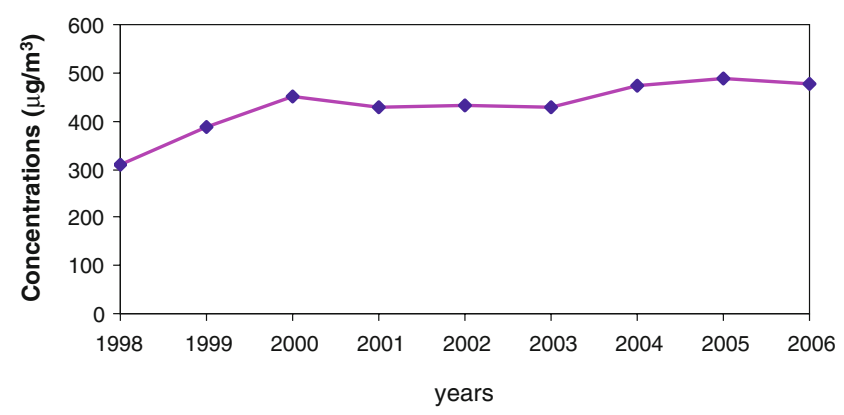

Fig. 2 Comparison of observed particulate concentrations from 1998 to 2006 d $\quad$ Site 4

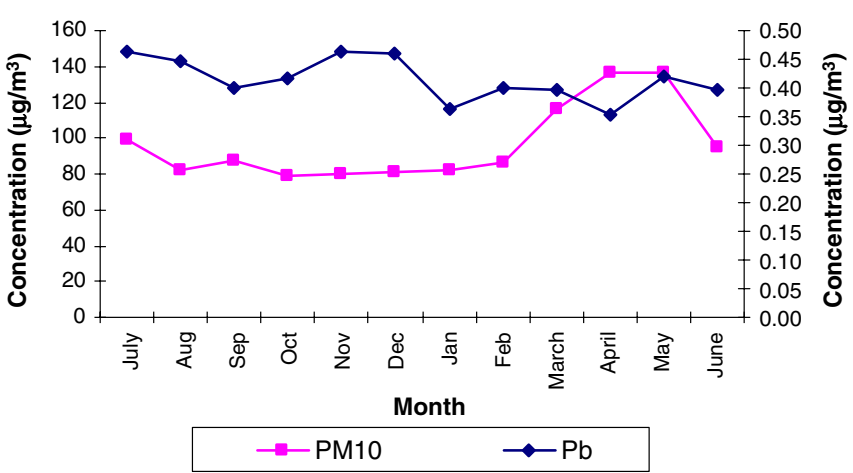

e

Site 5
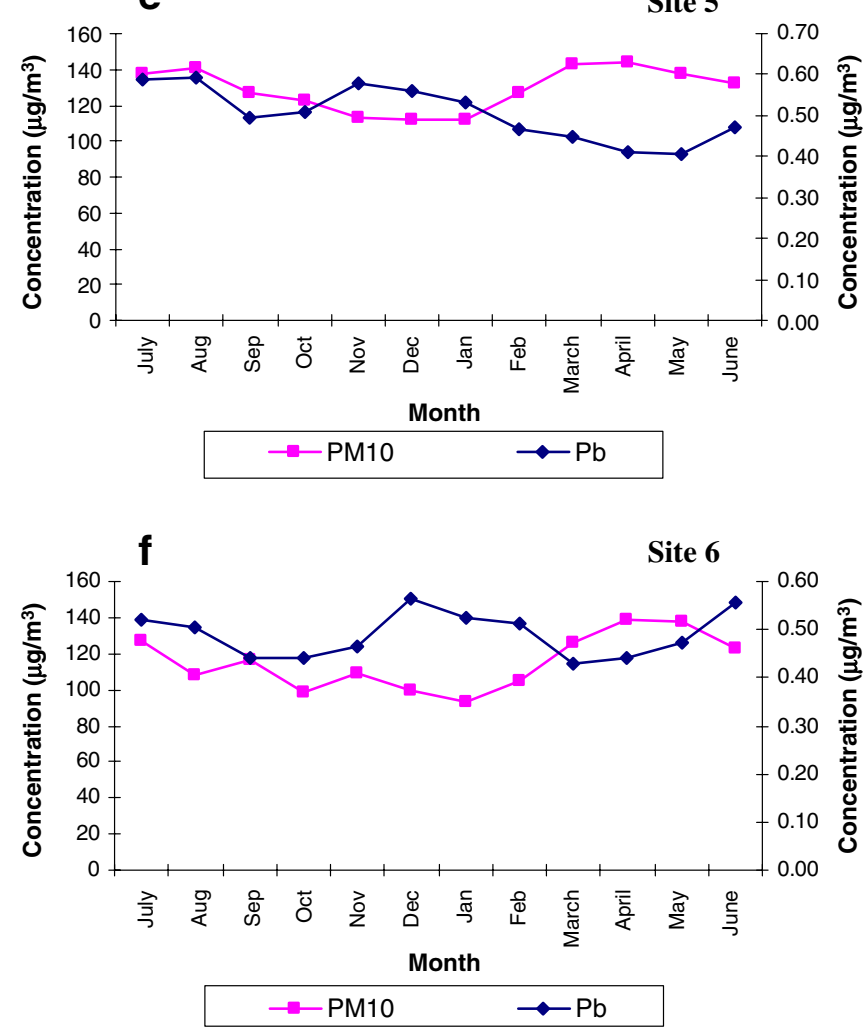

the concentrations for all the sites of measurements. The lack of good emissions factors from nontransportation sources might be one of the reasons for lower predicted concentrations.

\section{Conclusions}

In general, transportation, small-scale industries, and an elevated rate of combustion of conventional fuels for domestic and commercial purposes in the city are found to be the sources of particulate pollutants of the present investigation (Kulandai 2003; Adachi and Tainosho 2004). Except automobiles, the operation of diesel-powered gen- 
Fig. 3 a-f Comparison of predicted and observed PM10 concentration at different sites
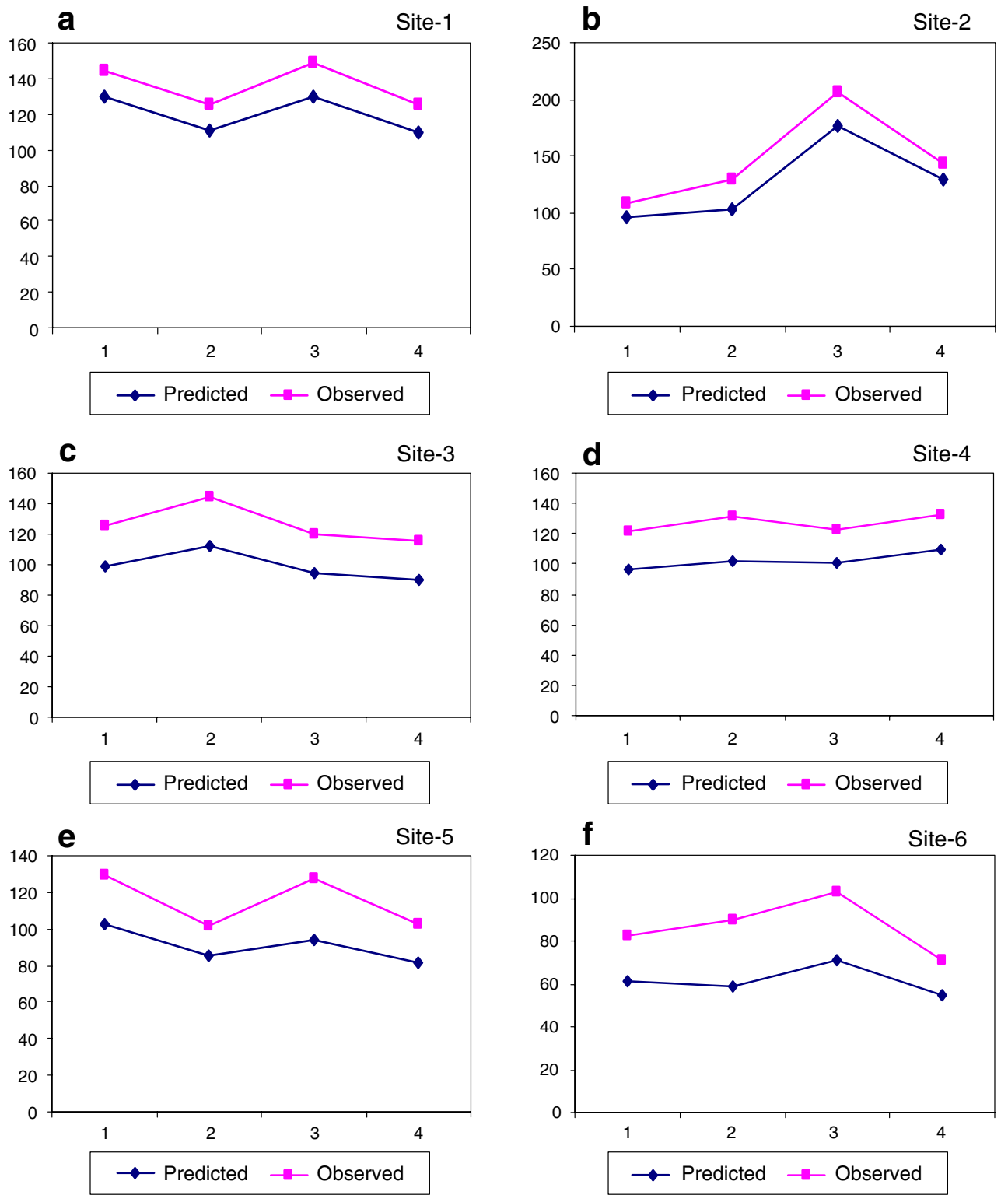

erators (which were used in commercial establishments during power failures especially at summer seasons), emissions from paved roads, and background concentrations from industrial and semi-industrial areas of the city also contribute to particulate pollution. Cooking in houses, school and commercial establishments, and refuse incineration in houses and public places and municipal incineration in open grounds may also contribute to the total pollutant load as well as the atmospheric particulate matter concentrations in an Indian city (Surya Prakash and Alappat 1999; Salve et al. 2006). The sand along the sides of the roads, which is dusty in nature, is not removed periodically all over the city. Hence, all these factors cumulatively contribute to the $\mathrm{PM}_{10}$ concentrations in the range of 88.1 to $226.9 \mu \mathrm{g} / \mathrm{m}^{3}$ in the city. Madurai is surrounded by agricultural lands, and so no potential sources are available in the vicinities of the city or from upwind sites.

Even though the $\mathrm{PM}_{10}$ pollution activities were widespread all over the city, it was noticed that during the period of experiment, Goripalayam endured the highest traffic densities among the sampling stations. The highest average concentrations of $\mathrm{PM}_{10}$ and lead at Goripalayam might be attributed to the pollution from automobiles. In fact, at this place, there were a large number of light-tonnage vehicles, especially motorized two-wheelers $(62,145)$, in the operation. Extreme congestion (resulting the slow movement of vehicles and random urban driving modes of operation), long waits at the signals, and traffic bottlenecks are observed commonly during the peak hours of traffic, as this site connects almost all the northern parts of the city 
(Tripathi et al. 2000; Katiyar et al. 2005). In addition, traffic-derived aerosol particles were emitted into the atmosphere due to abrasion processes of automobile components such as the brake or tire wear (Viana et al. 2006). Therefore, the emissions and abrasion of the components of automobiles might be the major contributors to the mass of total particles along with emissions from some small-scale industrial sources (Harrison et al. 2004). Traffic diversions from other parts of the city along the roads of this sampling station might be correlated with the maximum standard deviation that endured at Goripalayam.

The lowest concentrations of $\mathrm{PM}_{10}$ and lead were recorded at Sree Meenakshi temple sampling station, which could be considered as a sensitive area with the lowest traffic densities among the sampling stations. As the roads around this temple are one-way roads, the traffic density was very limited. In addition, there was restriction for the flow of heavy-tonnage vehicles in this area. The traffic survey results showed that at this site, a low number of automobiles were plying. Most of the vehicles that are operated in this area are gasoline-powered light-duty vehicles, which emitted almost negligible amount of particulates (Pundir et al. 1994; Jeba Rajasekhar et al. 2005; Gertler et al. 2006). The elevated buildings could restrict the background concentrations from the nearby semi-industrialized areas. It was also noted that among the commercial establishments, only a few are related to combustion activities. As the number of sources was substantially less, the calculated source strengths of particulate matter as well as the recorded concentrations of $\mathrm{PM}_{10}$ were also found to be low.

The experimental investigation on air pollution with special reference to average particulate pollutants revealed that the pollutants $\mathrm{PM}_{10}$ and $\mathrm{Pb}$ over Madurai were near to the permissible limits at all the sampling sites during most of the times of the year. It is worth mentioning here that $\mathrm{PM}_{10}$ has the permissible limits (for $24 \mathrm{~h}$ ) of 150,100 , and $75 \mu \mathrm{g} / \mathrm{m}^{3}$ for the industrial and mixed, residential and rural, and sensitive areas, respectively, whereas $\mathrm{Pb}$ has the permissible limits of $1.5,1.0$, and $0.75 \mu \mathrm{g} / \mathrm{m}^{3}$ for the industrial and mixed, residential and rural, and sensitive areas, respectively. However, $\mathrm{PM}_{10}$ has permissible limits (annual averages) of 120,60 , and $50 \mu \mathrm{g} / \mathrm{m}^{3}$ for the industrial and mixed, residential and rural, and sensitive areas, respectively, whereas $\mathrm{Pb}$ has the permissible limits of $1.0,0.75$, and $0.50 \mu \mathrm{g} / \mathrm{m}^{3}$ for the industrial and mixed, residential and rural, and sensitive areas, respectively. It was anticipated that with increase in the population, traffic, industrialization, and per capita energy consumption in the future might increase the emission load, which in turn will deteriorate the quality of the air more over Madurai. The increases in the atmospheric pollutant with this rate have created a threat for long-range adverse effects on the public health and social wellbeing of this city. The earlier studies pertaining to particulate pollution shows that the concentration of particulate pollutants shows an upward trend during the years. Therefore, the strict implementation of adequate abatement measures and environmental regulations are necessary for the pleasant present and the sustainable future. The AERMOD model under predicts patterns of $\mathrm{PM}_{10}$ by a factor of 1-1.5 in the concentrations. Hence, monitoring of $\mathrm{PM}_{10}$ concentration in the city over a longer period coupled with inclusive emission inventories for additional stationary sources are needed.

\section{References}

Adachi K, Tainosho Y (2004) Characterization of heavy metal particles embedded in the tyre dust. Environ Int 30:1009-1017

Balachandran S, Bharat RM, Khillare PS (2000) Particle size distribution and its elemental composition was estimated in the ambient air of Delhi. Environ Int 26:49-54

Benson PE (1989) Caline 4 - a dispersion model for predicting air pollution concentrations near roadways. Division of New Technology and Research, Department of Transportation, Sacramento, CA

Buckland AT, Middleton DT (1999) Nomograms for calculating pollution within street Canyons. Atmos Environ 33:1017-1036

Chow JC, Engelbrecht JP, Watson JG, Wilson WE, Frank NN, Zhu T (2002) Designing monitoring networks to represent outdoor human exposure. Chemosphere 49:961-978

Cimorelli AJ, Perry SG, Venkatram A, Weil J, Paine R, Wilson RB, Lee RF, Peters ED, Brode RW (2005) AERMOD: a dispersion model for industrial source applications. Part I: general model formulation and boundary layer characterization. J Appl Meteorol 44:682-693

Copper DC, Alley FC (1986) Air pollution control: a design approach. PWS, Boston, MA

Dockery D, Pope C, Xu X, Spengler J, Ware J, Fay M, Ferris B, Speizer F (1993) An association between air pollution and mortality in six US cities. N Engl J Med 329:1753-1759

EPA (2004) User's guide for the AMS/EPA regulatory model AERMOD. US Environmental Protection Agency, Research Triangle Park, NC

EPA (2005) Guideline on air quality models (revised). US Environmental Protection Agency, Research Triangle Park, NC (p. 40 CFR 51)

Espinosa AJF, Rodriguez MT, Alvarez FF (2004) Source characterisation of fine urban particles by multivariate analysis of trace metal speciation. Atmos Environ 38:873-886

Gertler A, Kuhns H, Abu-Allaban M, Damm C, Gillies J, Etyemezian V, Clayton R, Proffitt D (2006) A case study of the impact of winter road sand/salt and street sweeping on road dust reentrainment. Atmos Environ 40:5976-5985

Harrison R, Yin J (2000) Particulate matter in the atmosphere: which particle properties are important for its effect on health. Sci Total Environ 249:85-105

Harrison RM, Jones AM, Lawrence RG (2004) Major component composition of $\mathrm{PM}_{10}$ and $\mathrm{PM}_{2.5}$ from roadside and urban background sites. Atmos Environ 38:4531-4538

Hoek G, Schwartz J, Groot B, Eilers P (1997) Effects of ambient particulate matter and ozone on daily mortality in Rotterdam. The Netherlands. Arch Environ Health 52:455-459 
Jeba Rajasekhar RV, Muthusubramanian P (2004) Nitrogen oxides and lead air pollution in Madurai city. Asian J Microbiol Biotechnol Environ Sci 6:317-319

Jeba Rajasekhar RV, Tennyson D, Muthusubramanian P (2005) Vehicular emission loads of gaseous pollutants in Madurai city. Asian J Microbiol Biotechnol Environ Sci 7:427-430

Karar K, Gupta AK, Kumar A, Kanti Biswas A, Devotta S (2005) Statistical interpretation of week day/week end differences of ambient gaseous pollutant, vehicular traffic and meteorological parameter in urban region of Kolkatta. J Environ Sci Eng 47:164-175

Katiyar SC, Khathing DT, Dwivedi KK, Agarwal GD (2005) Vehicle density and SPM in ambient air in an urban area; Shillong (Meghalaya). Indian J Air Pollut Control 1:44-49

Katz M (1969) Measurement of air pollutants. Guide to the selection of metals. WHO, Geneva

Kesarkar AP, Dalvi M, Kaginlkar A, Ojha A (2007) Coupling of the Weather Research and Forecasting Model with AERMOD for pollutant dispersion modeling. A case study for $\mathrm{PM}_{10}$ dispersion over Pune, India. Atmos Environ 41:1976-1988

Kulandai S (2003) A study on suspended particulate matter and some heavy metal in the ambient air of Madurai city. Ph.D. thesis, School of Energy Sciences, Madurai Kamaraj University, Madurai, Tamil Nadu, India

Pundir PP, Jain AK, Gogia DK (1994) Vehicles emissions and control perspectives in India - a state of report. Indian Institute of Petroleum, Dehradun, India
Querol X, Alastuey A, Rodriguez S, Plana F, Mantilla E, Ruiz C (2001) Monitoring of $\mathrm{PM}_{10}$ and $\mathrm{PM}_{2.5}$ around primary particulate anthropogenic emission sources. Atmos Environ 35:845-849

Salve PR, Maurya A, Ramteke DS, Wate SR (2006) A study of air pollutants in Chandrapur. Indian J Environ Prot 26:742-747

Sammet J, Dominic F, Curriero F, Coursac I, Zegar S (2000) Fine particulate air pollution and mortality in 20 US cities, 19871994. N Engl J Med 343:1742-1747

Singal SP, Prasad R (2005) Analytical study of some observed micrometeorological data. J Air Pollut Control 1:44-49

Sivacoumar R (1990) Application of line source model for vehicular pollution prediction near roadways. M.E., dissertation, Centre for Environmental Studies, Guindy Engineering College, Anna University, Chennai, India

Stern AC (1976) Air pollution, vol. 1. 3rd edn. Academic, New York

Surya Prakash PV, Alappat BJ (1999) Control Strategies for automobile pollution. Indian J Environ Prot 19:185-192

Tripathi A (1994) Airborne lead pollution in the city of Varanasi, India. Atmos Environ 28:2317-2323

Tripathi RM, Vinod Kumar A, Raghunath R, Sastry VN, Krishnamoorthy TM (2000) Heavy metal in size separated atmospheric aerosol in Mumbai. Indian J Environ Prot 20:906-912

Viana M, Querol X, Alastuey A (2006) Chemical characterization of PM episodes in North-Eastern Spain. Chemosphere 62:947-956

Zar JH (2004) Bio statistical analysis, 4th edn. Pearson Education, Indian Branch, New Delhi, India 